\title{
Art framework for the industrial revolution 4.0
}

\author{
M. Mokhtar \\ Universiti Teknologi MARA, UiTM, Selangor, Malaysia
}

\begin{abstract}
The Industrial Revolution 4.0 (IR 4.0) had an impact on the form of art production and the art industry itself, eventually having huge implications for all of society and all aspects of life, including economy, education, and politics. The arts community needs to be aware and view the very broad framework of inter-art relationships and how IR 4.0 took place so that the production of the work is more relevant, up-to-date, and progressive. Several documents were reviewed to identify the dynamic framework of art within the IR 4.0. Art framework related to the IR 4.0 is detailed with components of the artist as co-creator, hybrid types of production, and attributes of a super smart society. Several key points should be referenced by humans so that they can be further prepared, better equipped, and more realistic for society 5.0.
\end{abstract}

Keywords: art framework, Industrial Revolution 4.0, society 5.0

\section{INTRODUCTION}

Among the factors of art development are international technology, the dynamics of artforms, and the art community itself. I-Suke (2020) reported that more than 15,000 visitors visited the Leonardo da Vinci exhibit at the National Art Gallery, Kuala Lumpur even though the work exhibited was just a reprint. Regardless, the advanced digital technology managed to captivate the audience and satisfy Malaysians who have only been able to see such artwork in books and movies. However, there are still some constraints in the art development.

In conjunction with the da Vinci exhibit, the display of Young Contemporary artwork caused surprises where there were works that were touched and damaged as a result of the behavior of the visitors, especially with regard to selfies. However, the gallery gave a clear justification regarding the adequate management of the exhibition operations. In a February 10, 2020 article from the Malaysiakini online newspaper, 10 Feb 2020 revealed the news was revealed that there was a release of four works by Ahmad Fuad Osman in the exhibit titled At the End of The Day Even Art Is Not Important even though the exhibition session is in progress. The realease was done by the gallery. The gallery took the action to control the confusion of the general public which the gallery said was not yet able to interpret the work at a higher level. In this case, the development of art needs to be driven wisely to cover all aspects that are in line with current developments.

\section{THE DYNAMIC OF MALAYSIAN ART IN THE INDUSTRIAL REVOLUTION 4.0 (IR4.0)}

The existence of IR 4.0 can be traced back to the 2000s. During that time, Malaysia experienced many deviations in social, political, and economic conditions. There are many kinds of art forms created in Malaysian art such as site-specific installation, web art, interactive CD, sound art, light art, performance, digital photography, alternative prints, fax, and mobile phone. In Table 1, Hasnul (2008) listed 35 paradigm shifts of modern to postmodern art styles that occurred in Malaysia. The table shows the variation in the processes, existence, output, performances, values, interpretation, and appreciations. At present, art forms have also become blurred with so-called painting, print, and 
Table 1. Paradigm Shifts by Hasnul (2008).

\begin{tabular}{|c|c|c|c|c|c|}
\hline FROM & TO & FROM & TO & FROM & TO \\
\hline Master narrative & Discourse & Centralize & Multicentered & Hierarchy & Network \\
\hline Aesthetic & Socio-politic & Linear & Nonlinear & Hand skill & Brain skill \\
\hline Formalism & Parody, hybrid & Form & Information & Goods & Services \\
\hline Modern & Post-modern & Fix & Change & Global competition & Global collaboration \\
\hline National & Global & Singular meaning & Multiple meaning & A passive audience & Interactive \\
\hline Exclusive & Participate & Product & Time & Physical attributes & Intellectual attributes \\
\hline Mass media & New media & Mass & Customisation & Specialization & Convergence \\
\hline Status quo & Deconstruction & Artist-centered & Audience-centered & Single direction & Cyclical \\
\hline Prescriptive & Choice & Review of end product & Review of process & Isolated specialist & Multi-skill generalist \\
\hline Nation state & Transnational & Independence & Interdependence & & \\
\hline
\end{tabular}

sculpture, thus a new media art term transpired in contemporary art. Suhana Nordin and Mokhtar (2015) stated that new media art required different understanding thus, the diversity of art, language and its principles needed to be highlighted. Besides hypertextual and virtual attribute in new media art, they added that the art medium itself represented as a message while data is the form.

A word dynamic can be understood as constant change with a positive value. The IR 4.0 launched at the World Economic Forum in 2016, showing that the boundary between the physical, digital, and biological will be more blurred. The situation is embodied through the elements of Artificial Intelligent (AI), Autonomous Vehicles, and the Internet of Things (IoT). The Malaysian Young Contemporary Art 2016 winner, Fuad Arif, created installation art, combining classical music synchronized with Quranic text translation animated on the screen and presented in a dark, closed gallery space. Visual and audio elements were combined with the spatial environment, requiring the audience to focus on whether to hear the sound or read the visual, to be in a real situational site or to meditate into the inner soul, or be able to adapt to everything at one time. Piliang (2018) stated that art development was really affected by the social-cultural environment. He added that the dynamic of its development is exaggerated by a dynamic community, network society, and the IR 4.0. For him, co-creator is the name of a "new" artist, who is no longer working alone. The form is also no longer the final production created by an artist but is art resulting from the ideas and an assortment of contributions. An established Malaysian sculptor, Ramlan Abdullah (2018), viewed other people to be part of his creative process. His public sculptures involved those who walked safely though his artwork in the city and those who participated along the creation. He added, art and technology are intertwined in the context of media application, human interaction, and the process itself. In 2017, Malaysia introduced Dasar Industri Kreatif Negara (DIKN) National Creative Industry Policy which catered to the enhancement of three major areas which are Creative Multimedia (film, advertising, design \& animation), Creative Art and Culture (crafts, visual art, music, performing, creative writing and fashion textile), and Creative Art and Heritage (museum, archive, restoration, and conservation). Since then, various initiatives were launched by several agencies in order to promote art locally and globally. Mazlan Othman (2019) in Senikini\#26 mentioned that the creative industry is the industry of the future in Malaysia.

Alvin Toffler (1990) mentioned that world technology control will be managed by those who have power in economics and politics. Since the IR 3.0 Malaysian art scene was supported by educational institutions, political power, and social dynamics, facing forward to the IR 4.0 there needs to be a high quality of a nation who engineered the success of the Industrial Revolution. Japan established society 5.0 attributes that are technology-based and human-centered. According to Yuko Harayama (2017), humans must remain the central actors and digitalization the means. There need to be initiatives to converge the physical space and cyberspace by fully utilizing ICT (Information and Communication Technology). Mayumi Fukuyama (2017) stated that all citizens are dynamically engaged through IoT, big data, robots, and AI, including culture and art. The uncertainty aroused among Thai artists and craftsmen as to whether or not change their art, craft, and design or to 


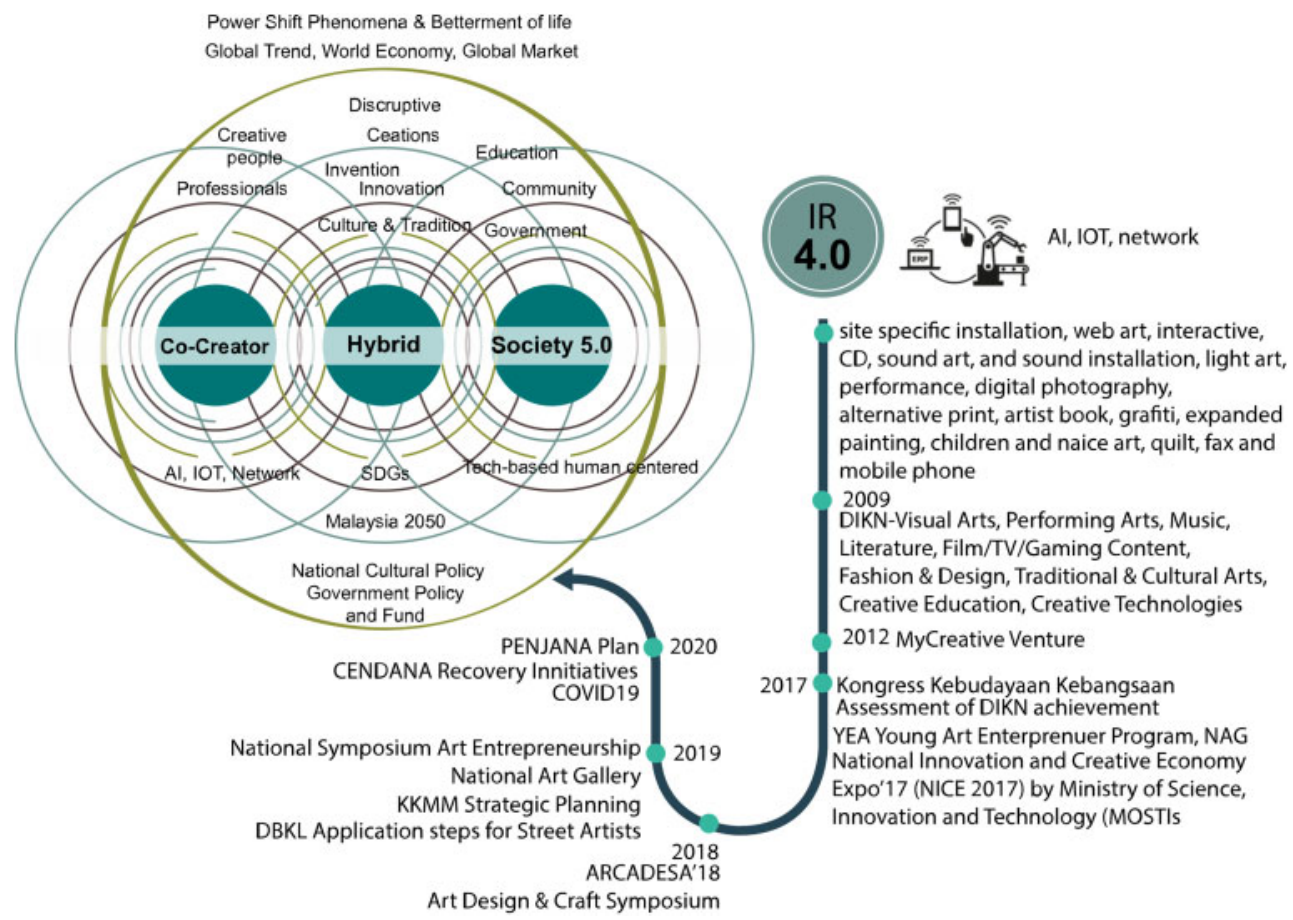

Figure 1. Malaysian art tagline and art framework in the Industrial Revolution 4.0.

preserve it. Consequently, Veerawat Sirivesmas (2018) stated that the main justification is based on an understanding of the history and culture before a paradigm shifts happen. Masterpieces, authenticity, and intellectual property have become new considerations in art production today. Since the Giclee print was introduced for high-quality digital art as original artwork, Intellectual Property (IP) and ownership certificates ideas for selling artwork instead of the tangible product itself. Javier Pes (2019) referenced Maurizio Cattelan's \$120,000 banana with duck-tape entitled "Comedian" which was eaten up as performance art. According to Cattelan, the banana work that was eaten is only a banana and is no longer a piece of real work. Ownership of the work is subject to the ownership of the original certificate.

\section{ART FRAMEWORK IN IR 4.0}

In Figure 1, an art framework for IR 4.0 shows how art functions and its current significance. The framework consists of components, linkages, and boundaries. The components of the art framework consist of co-creator, hybrid art form, and society 5.0. Every component is linked to each other and local cultural policies and other relevant government policies as well as financial allocation being an internal factor that controls the development of art in addition to external factors that are global in nature.

Co-creators consisted of multidisciplinary skills of an artist or professional team. They were creative people that endeavored with AI, IoT, and network system. With IR 4.0, creation of an art form converted to the hybrid mode either exists in actual things, simulated or virtual form, or a combination thereof. The creation of hybrid artwork occurred through the innovation, creation and even disruptive processes. When a work was produced by the process of collaboration it required an equivalent understanding or a clear agreement that ultimately produced the value of commonality. 
Local identity and cultural values are needed to overcome the challenges of global acceptance and the value of authenticity. Art for art's sake or art for society turned into to art that accomplishes the betterment of human life. Thus, the consideration of sustainable life is crucial nowadays. The sustainable development goals, or also known as SDGs ,involved every community. The individuals should be technology-based and human centered. They will be supported by various support systems, including the political power, economic stability and funding, education, and social interactions.

\section{CONCLUSION}

In conclusion, every component in the framework is interrelated and consists of local and global factors. The art form evolved according to the development of the technology introduced. Revolution is closely related to the keywords change, replacement, movement, flow, and improvement due to force, pressure, or coercion. The latest technology will take over the previous methods from various aspects of art production, including, materials, tools, systems, functions, processes, and how to appreciate them. Super smart artists as part of a super smart society today need critical and creative thinking skills. Not only that, but they also need to merge with other entities to produce a piece of work. Amalgamation of co-creators involving artists, AI, and robotic technology will be more interesting. Hybrid art and design generate a new language of art that opens up new understanding and appreciation. The definition of "beauty" and aesthetic will be transformed. It seems that art will be more subjective for most communities, but the fact is more intellectual as well as contextual for the super smart audience to "read" and communicate about art. For example, alternative prints maintain the concept of matrix in the understanding of print, but how the effect of the print is produced is so broad that the human brain itself is needed to print the shading effect of a material. The data will replace images that are typically treated as symbols or metaphors and need to be described, transcribed, and cryptographed as informative signs. As a creative human artist cannot not rely much on technology, they challenge themselves on how to manipulate it in order to express and execute creative solutions, ideas, and the betterment of the whole ecosystem. Living in a borderless world today has the potential to create social ills. To compete with technology, it is important that humans realize that they are still human created by the Great Creator and should know what the purpose of their life in the world is. It is up to the government, private agencies, institutions, and all communities to lead society in the right direction. However, true knowledge will guide us all to the perfect life.

\section{REFERENCES}

Ramlan Abdullah. 2018. The Transformation of Art Towards Industrial Revolution: A Case Study. The Construction of Langkawi Sundial From Idea, Fabrication and Installation. Proceedings of the Second International Symposium Art, Craft and Design in Southeast Asia 2018 ARCADESA\#2 (Facing the Challenges of $4^{\text {th }}$ Industrial Revolution). Malaysia: National Art Gallery \& faculty of Art \& Design, UiTM. pp. 32-33.

Bernama. 2020. February 11, 2020. Balai Seni Negara Sahkan Penurunan Karya Ahmad Fuad Osman, Available: https://www.astroawani.com/berita-malaysia/balai-seni-negara-sahkan-penurunankarya-ahmad-fuad-osman-230377. Retrieved September 22, 2020.

Mayumi Fukuyama. 2018. Society 5.0 Aiming for A New Human-Centered Society, Japan, SPORTLIGHT. July/August, pp. 47-50.

Wartawan Sinar Harian. July 15, 2020, Peluang Lihat Karya Agung Leonardo Da Vinci di Balai Seni Lukis. Available: https://www.sinarharian.com.my/article/37885/BERITA/Nasional/Peluang-lihatkarya-agung-Leonardo-Da-Vinci-di-Balai-Seni-Lukis. Retrieved September 22, 2020. (C) 2018 Hakcipta Terpelihara Kumpulan Karangkraf.

Yuko Harayama. 2017. Society 5.0: Aiming for A New Human-centered Society; Japan's Science and Technology Policies for Addressing Global Social Challenges. The Economist Limited 2017. 
Hasnul. 2008. Under-Deconstruction; Contemporary Art in Malaysia After 1990 in Timelines, Malaysia National Art Gallery, pp. 228-279.

i-Suke. 2020. Karya Agung Leonardo da Vinci Dipamer Dalam Bentuk Digital, Balai Seni Negara Catat Sejarah Terima Kunjungan Luar Biasa! The Star. Available: https://www.mstar.com.my/xpose/isuke/2019/ 08/01/pameran-mona-lisa. Retrieved September 22, 2020 Hakcipta Terpelihara (C) 2020. Star Media Group Berhad (10894D).

Jabatan Kebudayaan dan Kesenian Negara. 2019. Dasar Kebudayaan Kebangsaan. Retrived September 15, 2020. Available: http://www.jkkn.gov.my/ms/dasar-kebudayaan-kebangsaan

Malaysia Ministry of Communication and Multimedia.2019. Strategic Planning of Malaysia Ministry of Communication and Multimedia (2019-2023), pp. 55-66.

Mazlan Othman. 2019. Trusting Malaysian Creatives into the Future in SENIKINI\#26 Edisi Khas 10 Tahun Arthopea, Kuala Lumpur: National Art Gallery.

Mumtaz Mokhtar. 2019. Facing the Challenges in the $4^{\text {th }}$ Revolution Industry, in SENIKINI \#26 Edisi Khas 10 Tahun Arthopea, Kuala Lumpur: National Art Gallery.

Pes, J, (2019). Maurizio Cattelan's \$120,000 Banana Was Ejected From Art Basel Miami Beach After Drawing Unsafe Crowds (and Getting Eaten). Artnet News. https://news.artnet.com/market/cattelan-banana-art-artbasel-1725678

Suhana Nordin and Mumtaz Mokhtar. 2015. Discussion: Diversity in Malaysia, New Media Art. International Journal of Business and Administrative Studies I(3), 94-98. DOI: https://dx.doi.org/ 10.20469/ijbas.10003-3

Yasraf Amir Piliang. 2018. Co-Creation as A Basis of Creative Industry in The Era of Industrial Revolution 4.0. Proceedings Second International Symposium Art, Craft and Design in Southeast Asia 2018 ARCADESA\#2 (Facing the Challenges of $4^{\text {th }}$ Industrial Revolution). Malaysia: National Art Gallery \& faculty of Art \& Design, UiTM. pp. 11-19.

Veerawat Sirivesmas. 2018. The Shifting Paradigm, Beyond the Disruption of Design Crafts in Thailand, From the Perspective of Jewelry Design Instructor. Proceedings of the Second International Symposium Art, Craft and Design in Southeast Asia 2018 ARCADESA\#2 (Facing the Challenges of $4^{\text {th }}$ Industrial Revolution) Malaysia: National Art Gallery \& faculty of Art \& Design, UiTM. p. 20-25.

A. Toffler. 1991. Power Shift. United States of America: Bantam books Group, Inc.

A. Toffler. 1970. Future Shock; A Study of Mass Bewilderment in the Face of Accelerating Change. London: The Bodley Head.

-. 2020. Karya Ahmad Fuad diturunkan agar 'tak disalah erti'. Malaysiakini. https://m.malaysiakini.com/ hiburan/510342 